\title{
㐮胞様の臨床症状を呈した煩部リンパ管腫の 1 症例
}

永井䈐* ・藤田訓也**. 塚本周作**

待田順治* .玉利行夫**

\section{緒言}

リンパ組織の多く分布する顔面一口腔領域特に舌，口 唇部に执いてりンハ管腫の発生することはまれではない， しかしながら，顔面煩部に発生し，しかも多量の内容液 を含有するリンパ管腫はまれである。ささらに裂胞を形成

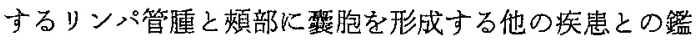
別診断は重要な事柄である. 今回われわれは煩部に発生 し，多量の内容液を含有するリンパ管腫に括いて，その 穿刺内容液の諸検査により他の裂胞形成疾患との鑑別診 断を行ない，本腫痬の禳胞壁に開空術を施すことにより 治瘾した症例に遭遇したので，ここに報告する。

\section{症例}

患者：姓 27 才主㷌

初猃: 昭和 40 年 5 月

主訴：右側顔面頓部の腫脹,

家族歷：特記すべき事項なし。

既往歴：昭和 39 年 8 月頃, 右側煩部の㶵痛性嗹脤に 気づく，直ちに某院に受診するも脂肪腫を矤方ししるを いう診断のみで確定診断を得られず，処置も行なわず放 置していた，以後同部の腫脤の增大，減少を反復した。

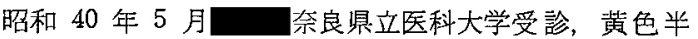
透明の液体を翼胞穿刺炕より認め，未処置のまま当科を 紹介されて来院した。

現症：体重 $56.5 \mathrm{~kg}$, 血圧 120 78, 眽搏 72 で体格 および栄養状態は良好である. 碩下および靧下りンパ腺 の腫脹なく，他に認むべき異常はない、

局所所見：石側顔面煩部に鷄卵大の無痛性，做漫性腫 脹を認め，弾性軟である(写真 1 )。口管内は $\overline{7} \overline{65}$ に

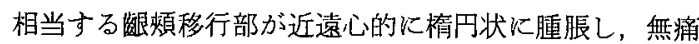
性，桷漫性で，軽度の波動を認ぬる(写真 2 )，歯牙は骨 植堅固で歯列も正常であり，顎骨の異常は認められな い, 穿刺に上り約 $7 \mathrm{cc}$ の黄色半透明の液状内容液を認 む.

臨床検查所見 血液所見一赤血球数 433 万，白血球数 8200 ，中性好性白血球 $71 \%$ ，酸好性白血球 $4 \%$ ，塩基 好性白血球 $1 \%$, リン八球 $23 \%$, 大単核白血球 $1 \%$, 血小板数 14.6 万，血色菜量 $15.3 \mathrm{~g}$ ，へマトクリット $44 \%$ ，出血時間 4 分，凝固時間 8 分，血液型 $\mathrm{O}$ 型，梅埥

\footnotetext{
* 大阪大学歯学部口腔外科学第 1 教室
}

** 大阪大学齿学部口腔外科学第 2 教宣

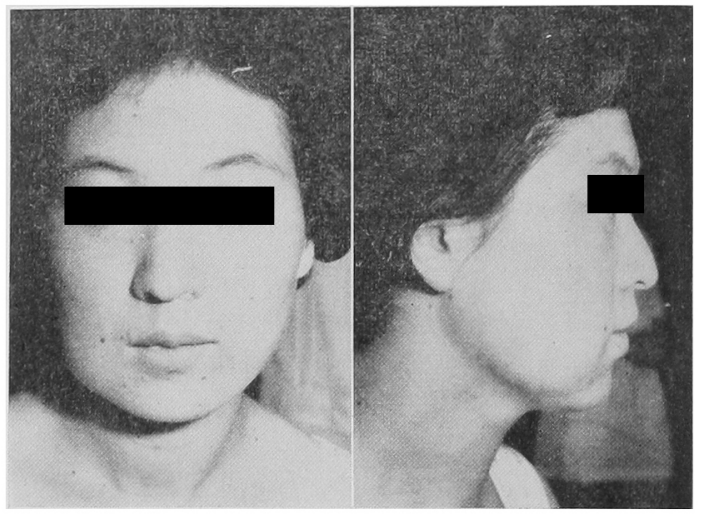

写真 1 㭧者の前貌㔚よび側貌（右側）

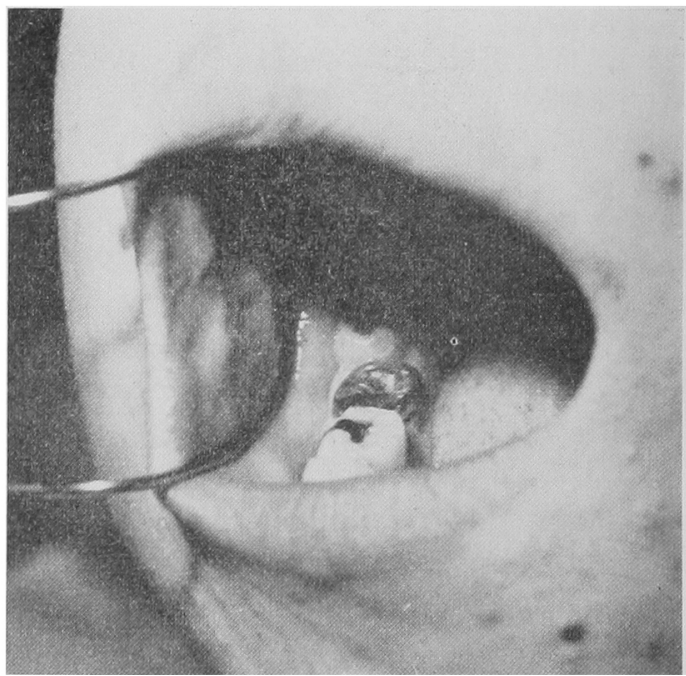

写真 2 術前口腔所見

血清反応陰性.

穿刺内容液検查所見：穿刺内容液は室温で試験管中に 放固して执くと，約 10 分間で黄色半透明の上澄液と不 透明な灰白色沈渣 3 対 1 K分離する.

1）穿刺液の塗抹鏡检一上澄液のギムザ染色による塗 抹標本は写賣 $3 に$ 示すごとく，大部分は濃染性のリンパ 球でしめられ，わずかに赤血球を認めるのみである.

2）呀刺液のアミラーゼ測定一Bernfeld 法”により上 澄液のアミラーゼ測定を行なつた結果は 4.2 unit $/ \mathrm{m} l$ で あつた。 


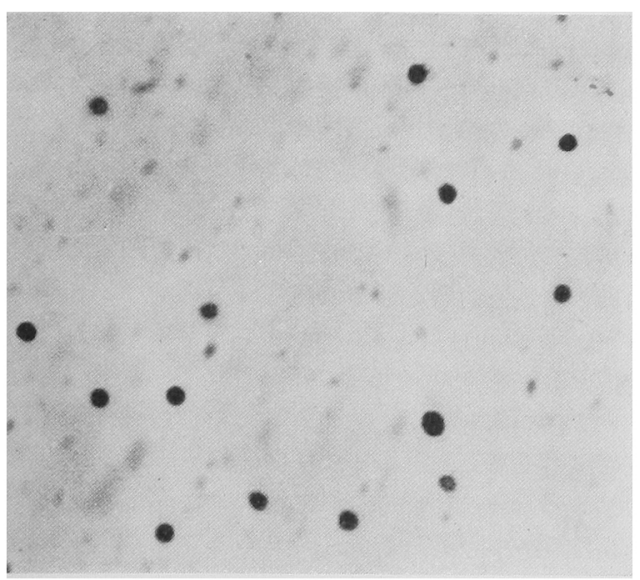

写真 3 内容液の組織所見

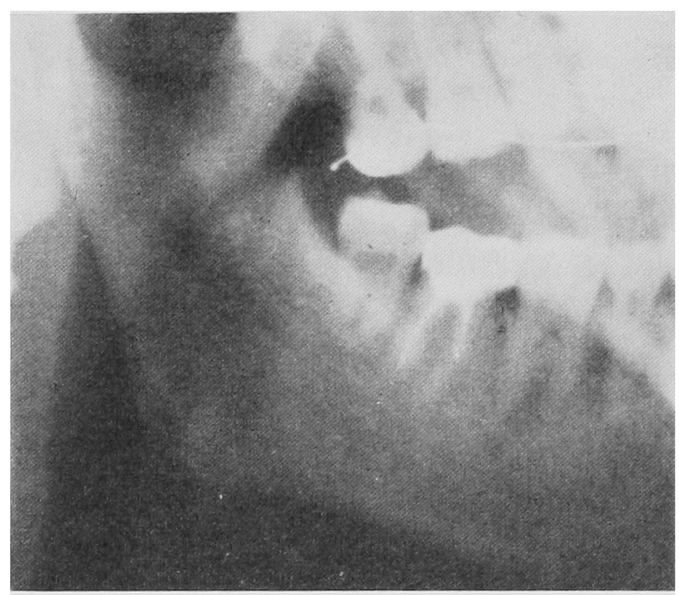

写真 4 側方撮影のレントゲン像

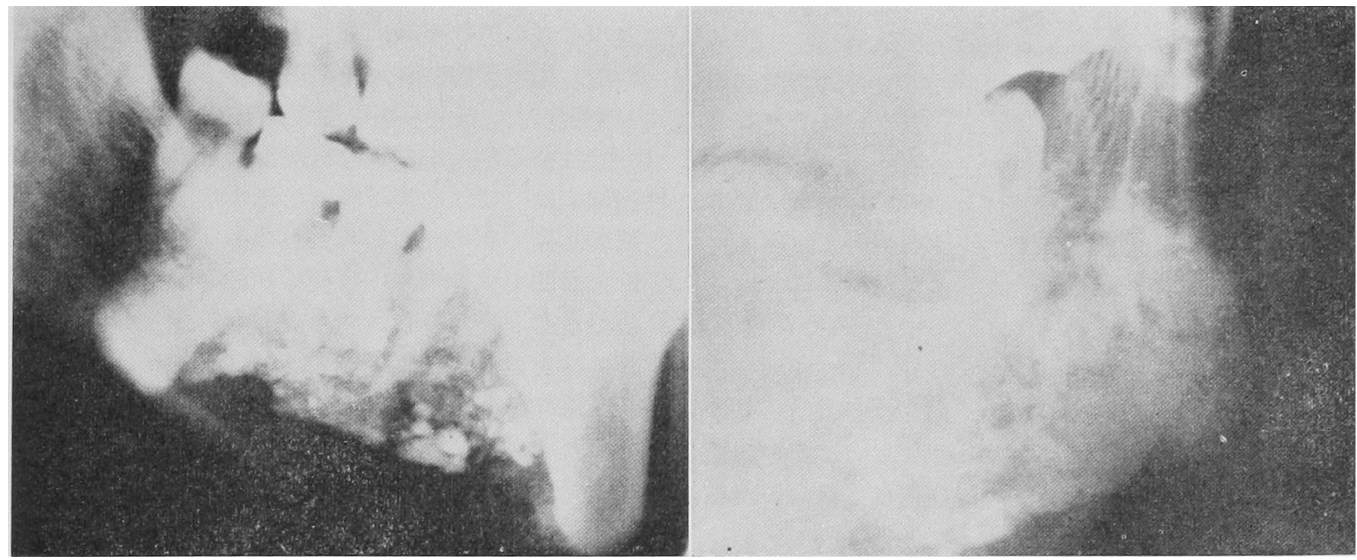

写真 5 造影刻注入後の側方および前額後頭方向撮影のレントゲン像（ 5 分後）

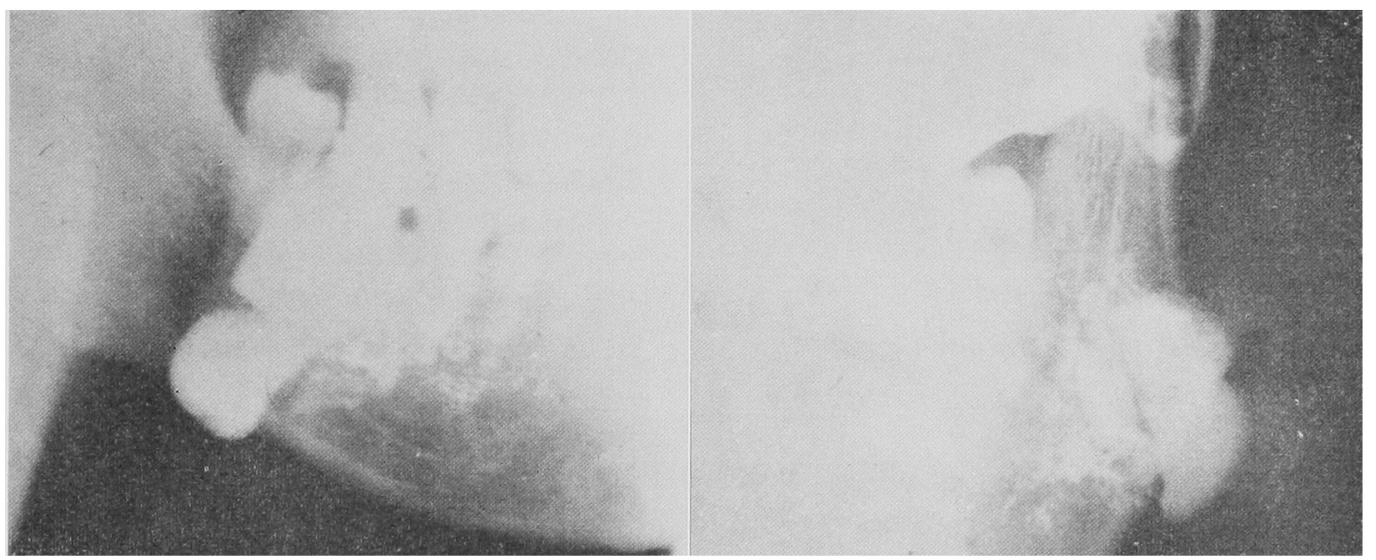

写真 6 造影凪注入後の側方および前額後頭方向撮影のレントゲン像（1時間後） 
3）穿刺液の細菌検査一塗抹鏡検，培養ともに細菌を 認めなかつた

レントゲン所見：右側下顎骨を中心とする側方レント ダン撮影に拈いては，顎骨にはレ線上なんら異常を認め

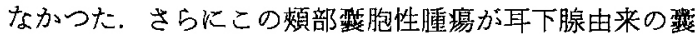
胞であるか否かを决定するため，耳下腚造影の目的で右 側耳下腺尊管開口部より細い消息子を㧴入したが導管開 口部より約 $3 \mathrm{~cm}$ で抵抗があり，それ以上挿入不能で耳 下腺造影は出来なかつた（写真 4)，写真 5 は娈胞内容液 を一部穿刺吸収し，露胞内に $40 \%$ モルヨドール約 $5 \mathrm{cc}$ を注入し，注入 5 分後の側方掫影および前額後頭方向撮 影のレントゲン像である。7穵中心として棈円形の造 影剤によるレ楾不透過像が認められる. 写真 6 は造影剂 注入 1 時間後のレントゲン像である. 造影風の垔胞周国 への拡散は著明であり，特に $\overline{7}$ より近心側への拡散が 認められる。

臨床診断：右側煩部聚胞性腫瘍.

処置および経過：米院時より 3 回にわたり窂刺を行な つた. 昭和 40 年 8 月、阪大函学部附属病院口腔外 科に入院, 同年 8 月以上記監床診断のもとに露胞壁の 開空術を行なつた。すなわち $2 \%$ プロカイン局所麻酔の もとに被㠅粘膜および裂胞壁を $\overline{5}$ の部位より $\overline{7}$ にわ たり棈円形に切除した，楼内は $1 \mathrm{~cm}$ 内外の胞が多房 珄に，複雑に入りくみ，中心部に血管の走行も観察され

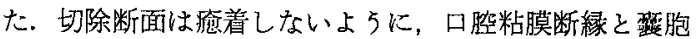
断縁とが疮着するように切除縁にとつて綘合した，最後

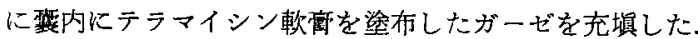
術後 3 回ガーゼ交换を行ない，10 日後に抜系した, 術後 約 1 力月で磷胞底よりの肉第の增殖により，霆胞腔は完 全に消失した，術後約 1 年を経過した現在，腫塨の再発 は認められず，経過は良好である。

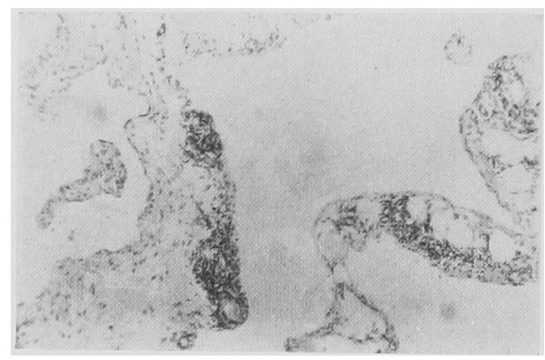

写真 7 病理組織所見

病理組織学的所見 . 腫瘍組織は不規則に拡張した大， 小のリン八管より形成されており，線維性結合織およひ 脂肪組絊中にリンパ球の漫潤が認められる，従つて病量 組織学的には海綿樣リンパ管腫と診断される(写真 7).

\section{総括ならびに考案}

リンパ管腫の口整領域の発生夏度に関しては Shklar and Meyer ${ }^{2)}$ が述べているごとく，口腔領域の脈管系の 腫瘍のうちでは，リンパ管腫は血管嗹につぐ頻度で発現 するものであり，脈管系腫痬 694 例中リンパ管腫 29 例, 血管腫 354 例であり，口腔領域にリンパ系組織の分布が 多く, リンパ管腫の発現の可能性は大であると考文られ るが，血管腫に比較すればかなりの低頻度である。 口腔領域の器官別リンパ管腫の発生頻度は舌, 煩粘膜,

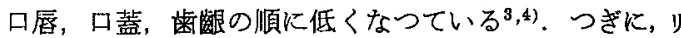
ンパ管腫は病理学的に単純性リンパ管腫，海綿様リンパ 管腫，簬胞性リンパ管腫に分類されている5 .さらにり ンパ管腫の本熊は新生物よりも，むしろ過誤腫もしくは 発育渏型と考えられている. 間仁田4によれば口腔領域 のリンパ管腫は病理像の面に抏いて，海綿様リンパ管腫 と襄胞性リン，管腫が混在していることがあると指摘し ている，本症に批けるリンパ管尰は，病理組織学的には 海綿様リンパ管腫であつたが，多量の内容液を含有する リンパ管腫であり，臨床的には雅胞性リンパ管腫に属す るものと考元られる。

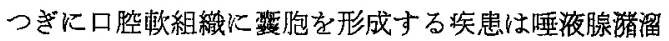

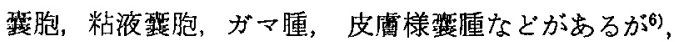
本症例のごとく，煩部に䠗胞を形成したリンパ管腫と，

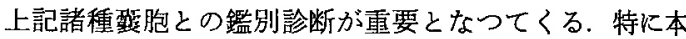
症例においては，耳下腺に由来する㵔溜露胞との鑑別診 断が必要であつた。われわれは本症例において，鑑別診 断の目的で㖶胞内の内容液の組織学的，生化学的検查と 禁胞造影とを試みた。すなわち㗪胞性リンパ管腫の内容 液には少量の蛋白と多量のコレステロールが，また内容 液沈椬には落脱上皮とわずかに白血球，赤血球が含有さ れると Moore 》 は述べている．しかしリンパ管腫内容液 は桃色もしくは桃白色で赤血球は含まれないという報告 当ある2. われわれの行なつた内容液のギムザ染色によ る塗枺鏡検に批いてほとんどがリンパ球でしめられてお り，赤血球はわずかに認められるのみで女つた。つぎ Bernfeld 法”により対照として行なつた人漉合車液のア ミラーゼ含有量は 1480 unit $/ \mathrm{m} l$ であり，また家鬼耳下 腺睡液のアミラーゼは1000〜3000 unit $/ \mathrm{m} l$ である，本症 の穿刺内溶液のアミラーゼ測定ではわずかに4.2unit $/ \mathrm{ml}$ を含有するのみであつた，さらに菲胞造影に括いて，造

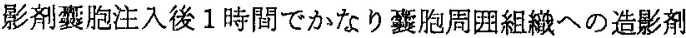
の拡散が観察された．以上穿刺内容液の塗抹鏡検におい て多量のリンパ球が磼認され，内容液中のアミラーゼ含 有量が唾液中のそれに比して非常に少ない值を示し，変 胞内造影剂の周囲組䄉への拡散速度が非常に大であるこ とより，本症例の歌胞は最も鑑別診断を要すると思われ

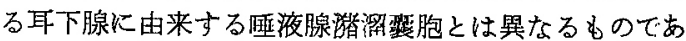

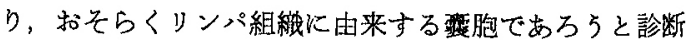
されたこのことは较胞内容液の組織学的, 生化学的榆 榃がある程度疾患の診断もしくは鑑別診断に役立つもの であることを示㖫している。 
リンパ管腫の療法に関しては, 腫陽組織の切除, 放射 線療法 ${ }^{8)}$ ，硬化剂这入法 ${ }^{91}$, 電気烧灼法 ${ }^{8)}$ がある。これら 療法の5 万放射線療法はリンパ管腫の放射線に対寸る抵 抗性が高く好結果汢期待出来ない。また硬化刜注入法に 関しては Stockdale ${ }^{9)}$ の好結果の報告もあるが完全な治 瘉は望めない、リンパ管腫の外科的処置に関しては Thoma $^{8)}$ も述べているごとく喠癔の完全切除の他に口腔 領域のよ5に切除による機能面の障害を考虑にいれた場 合は，腫瘍組織の部分切除を反復しておこな5のが最良 である。また，珵胞性リンパ管腫に拈いては内容液の破 綻の又の処㗐で自然治疮がまれに観察されている10) 本 症例ではリンハ管腫琵胞の開空術をおこならことにより 完全な治洨を子、術後約 1 年を経過するも再発の傾向は 認められない。この事実はリンパ管腫の5ち覇胞を形成 し，腫瘍組織の周囲組織への浸潤が少ないリンパ管腫で は，箦胞壁の開空に上る内容液の排出に上り，治痹に㴘 かれることがあることを示唆している。

\section{結論}

本症例は 27 才女性で右側煩部に琵胞を形成したリン パ管腫に対し，穿刺内容液の組織学的，生化学的検査な らびにレ線検査などを污こない，同部に発生する他の型
胞形成疾患との鑑別夑断をおこない，裂胞壁に開空術を 施すことにより治沲をみた比較的興味深いものである。

\section{文献}

1) Colowick, S.P. and Kaplan, N.O. Methods in Enzymology. Vol.1. Academic Press inc., Publishers, N. Y. 1955, p. 149

2) Shklar, G. and Meyer, I. Vascular tumors of the mouth and jaws. Oral Surg., Oral Med. and Oral Path. 19 (3): 335 358, 1965

3) Lichtenstein. J., Kopp, W. K. and Post, A. : Lymphangioma : Anlage proliferation induced by chronic irritation. Oral Surg., Oral Med. and Oral Path. 20 (3) : 363 366, 1965

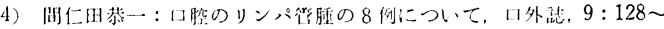
135, 昭 38 .

5) Anderson, W.A.D. . Pathology. 4ed., C. V. Mosby Company. St Louis 1961, p.576

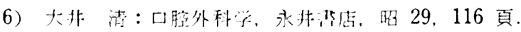

7) Moore, R. A. : Textbook of Pathology. 2ed., W.B. Saunders Company, Philadelphia and London, 1952. p. 800

8) Thoma, K. H. : Oral Surgery. 3ed., C. V.Mosby Company, St. Louis, 1958, p. 1120

9) Stockdale, C. R. . Peripheral angiomas and their treatment with sclerosing solution. Oral Surg., Oral Med. and Oral Path. 12 (10): 1157 1162, 1959.

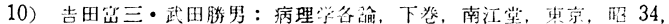
135 頁. 